\title{
The importance of rock-log calibration for a correct evaluation of the Carapebus Formation reservoirs in the Parque das Baleias, Campos Basin, offshore Brazil.
}

Matheus Lima Lemos de Oliveira, Antonio Fernando Menezes Freire, Wagner Moreira Lupinacci, Anderson Rafael Rezende Alves.

\author{
Universidade Federal Fluminense - UFF
}

Copyright 2019, SBGf - Sociedade Brasileira de Geofísica

This paper was prepared for presentation during the $16^{\text {th }}$ International Congress of the Brazilian Geophysical Society held in Rio de Janeiro, Brazil,19-22August 2019.

Contents of this paper were reviewed by the Technical Committee of the $16^{\text {th }}$ International Congress of the Brazilian Geophysical Society and do not necessarily represent any position of the SBGf, its officers or members. Electronic reproduction or storage of any part of this paper for commercial purposes without the written consent of the Brazilian Geophysical Society is prohibited.

\section{Abstract}

The Parque das Baleias, located in the northern part of Campos Basin, is a region that contains fields with expressive volumes of petroleum in the pre-salt and in the post-salt domains. The Carapebus Formation contains the most important post-salt reservoirs in the area, constituted by turbiditic deposits from the Upper Cretaceous to the Lower-Miocene. Due to the complex geometry and heterogeneity, the evaluation of these reservoirs is a challenge in terms of petrophysical studies. This work analyses the Carapebus Formation based on well logs and calibrated with the description of rock samples to study the lithological heterogeneities in the reservoir. The evaluation in terms of log facies, porosity and clay volume exhibits the sandstones heterogeneity in terms of grain size and selection, with intercalations of siltstones and shales that segment the reservoir in zones. Also, the presence of feldspars in sandstones motivated the use of different methods to assess the clay volume and evaluate the quality of reservoirs.

\section{Introduction}

The study of facies recognition and distribution is one of the many steps carried during the reservoir characterization, whose application aims to improve the management of projects in hydrocarbon producing fields. Understanding the distribution of the reservoir-facies that presents the best characteristics in terms of porosity and permeability adds accuracy to production predictions and decreases exploratory risk on future drillings.

The calibration of well logs with rock data, when available, is a critical step for a correct lithological interpretation and corroborates to determine and analyze log facies in the interval of interest in a prospect. The objective of the rocklog calibration is to reduce uncertainty in log interpretation, providing information to the study, such as the lithological description of plugs and the distribution of physical and chemical properties of a reservoir (Schuab, 2015).
The Parque das Baleias (Figure 1), studied in this work, is a complex of fields located over the northern area of the Campos Basin, with explorations at a water depth between 1300 and 1600 meters. In the recent years, important reservoirs with expressive volumes of oil were discovered in the region. The area is in evidence for locating some of the most prolific fields in terms of oil production in Brazil with Carbonatic reservoirs from the Aptian and turbidite reservoirs from the Upper Cretaceous to the Eo-Miocene (Dias, 2018).

In turbiditic reservoirs, such as the ones in the Campos Basin, architectural, petrophysical and facies variations observed along the deposit (Moraes et al., 2006; Morais, 2017) exemplifies the complexity to detect analogies between features in different temporal scales (Mutti and Normark, 1991). The turbiditic reservoirs between the Santonian and the Upper Oligocene of the Carapebus Formation (Fm.), in the Parque das Baleias Field Complex are the focus of this study.

This work presents the objective to propose an approach for well log interpretation combined with the description of rocks, in a way to study the heterogeneity of lithological facies present in the Carapebus Fm.. To evaluate the method, a lithological log was interpreted based on rock samples descriptions and on log facies observed in gamma-ray (GR), caliper (CAL), resistivity (RES), density (DEN), neutron (NEU) and sonic (DTC) curves of Well 4BRSA-420, shown in Figure 1. In addition, petrophysical properties were evaluated in the reservoir, such as clay volume and porosity, to comprehend the influence of facies distribution in the reservoir quality.

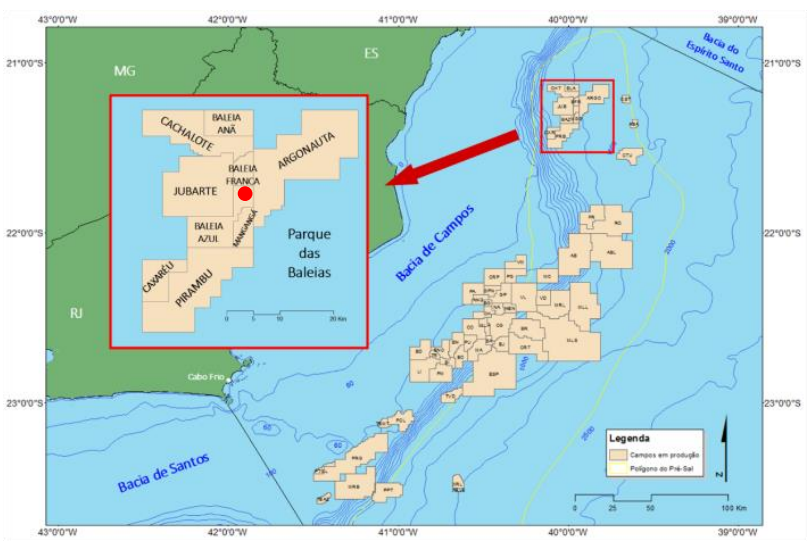

Figure 1: Location map of the Parque das Baleias, Campos Basin. Well 4-BRSA-420 is highlighted in red on the detailed map. Adapted from Dias (2018). 
The other method to porosity estimation uses the sonic log (PHIS) (Nery, 2013). This equation uses the matrix transit time interval $\left(\Delta t_{m}\right)$, the

\section{Methodology}

Well logs and rock samples descriptions of Well 4-BRSA420 were imported and analyzed in the interval 2573/2635 m, in which comprises the Carapebus and Ubatuba Formation, that are part of the turbiditic system of the Oligocene in the Campos Basin.

Initially, samples descriptions were grouped in terms of lithology, granulometry, roundness, sorting and mineralogical composition. According to these descriptions, it was possible to individualize and compare distinct sandstone reservoirs in the Carapebus Fm., presenting different depositional characteristics.

A lithological log (Figure 2) was interpreted using the rock descriptions and the well logs: gamma-ray (GR), caliper (CAL), resistivity (RES), density (DEN), neutron porosity (NEU) and compressional sonic (DTC). On the basis of the sidewall samples' descriptions and the log facies, a total of six lithologies were observed in the interval of study:

1. Conglomeratic sandstone;

2. Sandstone;

3. Siltstone;

4. Diamictite;

5. Shale;

6. Marl.

Then, with the purpose of evaluating some petrophysical properties of the reservoirs, logs were calculated according to the methods described below:

a. DRDN log: this curve is calculated from the normalization of the density (DEN) and the neutron (NEU) logs. It indicates the presence of sandstones interpreted from the crossover of the two well logs (Guimarães, 2008). Negative DRDN values indicate the presence of sandstones and positive values indicates other lithologies such as shale, marl and diamictite:

$$
D R D N=\left(\frac{D E N-2}{0.05}\right)-\left(\frac{0.45-N E U}{0.03}\right)
$$

b. Porosity: two methods were used to calculate the sandstones porosities. The first using the density log (PHID) (Nery, 2013). This equation uses the matrix density $\left(\rho_{m a}\right)$, the density of the fluid in the pores $\left(\rho_{f}\right)$ and the density measured on the DEN log $\left(\rho_{b}\right)$ :

$$
\text { PHID }=\frac{\rho_{m a}-\rho_{b}}{\rho_{m a}-\rho_{f}} .
$$

fluid transit time interval $\left(\Delta t_{f}\right)$ and the interval time measured on the DTC $\log (\Delta t)$.

$$
\text { PHIS }=\frac{\Delta t_{-}-\Delta t_{m}}{\Delta t_{f}-\Delta t_{m}}
$$

c. Clay volume: likewise, two methods were used to calculate this curve. One using the Larionov method for tertiary rocks $\left(V C L_{\text {Larionov }}\right)$ (Asquith, 1999). This method estimates the clay volume in the rock using the gamma-ray log (GR) and the gamma-ray index (GRI), that is defined by the baselines of sand $\left(G R_{\min }\right)$ and shale $\left(G R_{\max }\right)$ in the GR log.

$$
V C L_{\text {Larionov }}=0.083 *\left(2^{3.7 * I G R}-1\right) \text {, }
$$

$$
G R I=\frac{G R-G R_{\min }}{G R_{\max }-G R_{\min }}
$$

The other method to estimate the clay volume uses the density porosity (PHID) and neutron (NEU) logs $\left(V C L_{N D}\right)$ (Nery, 2013; Souza, 2014). The equation uses the porosity measured on the NEU log $\left(\phi_{N}\right)$, the porosity measured on the density porosity log $\left(\phi_{D}\right)$, the apparent porosity of a shale measured on the NEU log $\left(\phi_{N s h}\right)$ and the apparent porosity of a shale measured on the density porosity log $\left(\phi_{D s h}\right)$.

$$
V C L_{N D}=\frac{\phi_{N}-\phi_{D}}{\phi_{N S H}-\phi_{D S H}}
$$

Finally, 5 sandstone zones (Figure 2) were identified in the Carapebus Fm. and their petrophysical properties were analyzed to evaluate the quality of potential reservoirs.

\section{Results and Discussion}

Figure 2 presents the interval 2573/2635m, which evidences the Carapebus and the Ubatuba Formations in the Oligocene, along with the well logs. The interpreted lithological log, calibrated with the rock descriptions, can be compared to the lithological log provided by the drilling company. 
Determining the relationships between logs and sidewall samples assisted on defining the log facies. In Figure 2, the presence of marls is indicated by the decrease on the GR and DTC logs and the increase on the DEN and NEU logs.

The diamictite lithology is evidenced by an expressive increase of the GR log, associated with the NEU log on the left of the DEN log, relatively separated. Shales are identified by the relative increase on the GR log and decrease on the RES log, associated with the NEU log separated and on the left of the DEN log. The sandstone and conglomeratic sandstone lithologies deserve special attention in this analysis, since they present relatively high GR values (Table 1).

Nevertheless, sandstone lithologies can be observed when the DEN log crosses over the NEU log, in which the density decreases and the neutron porosity increases. The calculated curve DRDN helps to interpret sandstones, indicating its occurrence on the negative intervals of the log. Finally, the siltstone lithology is interpreted based on the cross-over between the logs
DEN and NEU, but with small separation between the curves. The Table 1 quantifies and summarizes the log measurements of the lithologies observed in Figure 2.

It can be noted on Table 1 that the sandstone and conglomeratic sandstone lithologies present higher GR values in comparison to standard clean sands (Rider, 2002). According to lateral-sample descriptions, it can be perceived the presence of feldspar (FLD) as an accessory mineral of these the sandstones (Fig. 2). K-feldspars are source of radioactivity due to the presence of $\mathrm{K}^{40}$, which naturally produces high measurements on the GR log (Asquith, 2004).

Therefore, the high GR measurements for sandstones in this formation could possibly be interpreted as a response of feldspar instead of the presence of clay. K-feldspars are source of radioactivity due to the presence of potassium, in which naturally produces high measurements on the GR log (Asquith, 2004). Therefore, the high GR measurements for sandstones in this formation could possibly be interpreted as a response of feldspar instead of the clay presence.

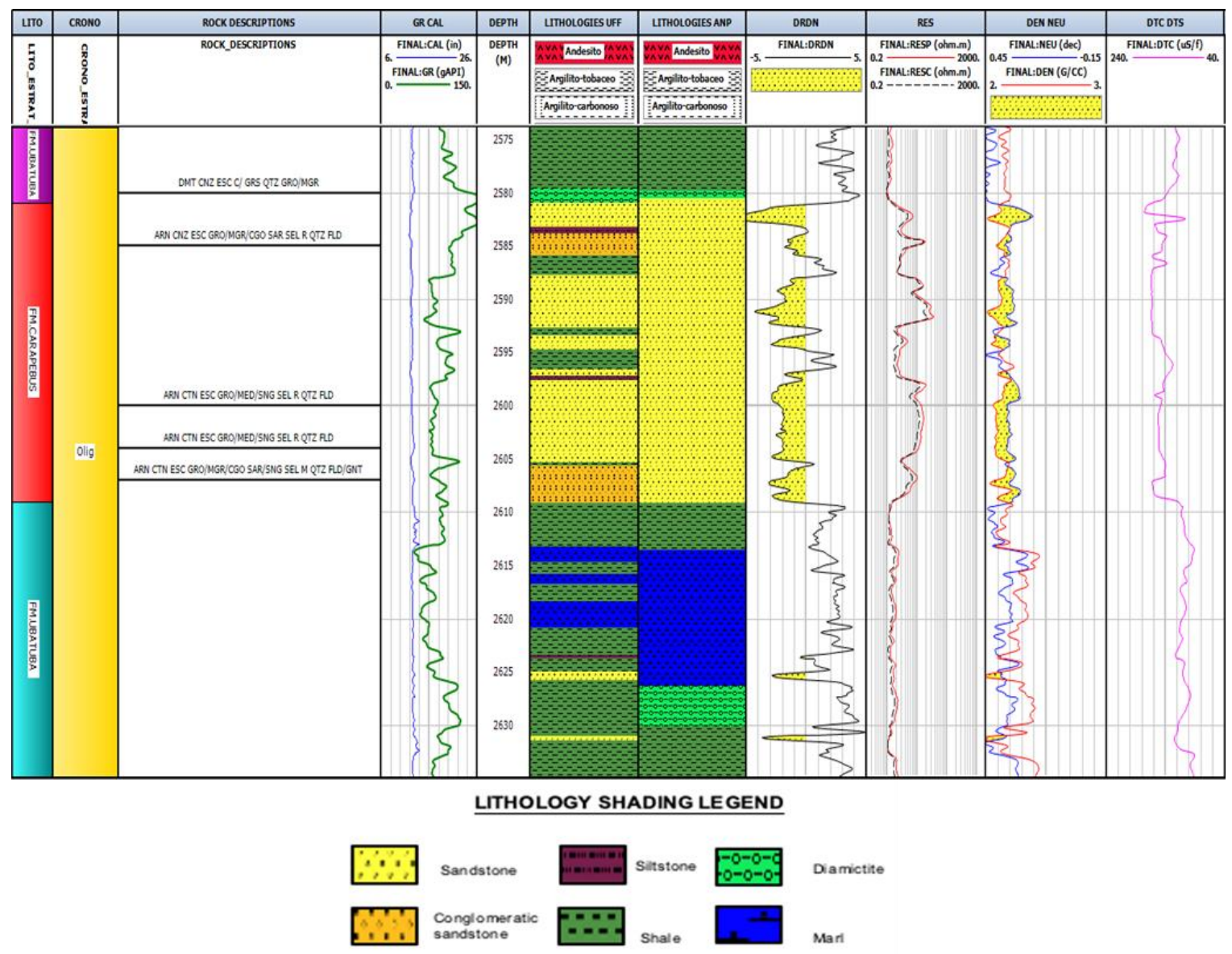

Figure 2: Logs and rock descriptions of Well 4-BRSA-420, interval 2573/2635m. Track 1: lithostratigraphy; Track 2 - Chronostratigraphy; Track 3: rock samples descriptions; Track 4 - GR and CAL logs; Track 5 - depth; Track 6 - lithology log interpreted in this work; track 7 lithology log provided by the Composite Log (ANP); Track 8 - DRDN log; track 9 - RES log; Track 10 - DEN and NEU logs; Track 11 - DTC $\log$. 
Table 1: Measurement intervals (minimum - maximum) for each lithology interpreted on this study.

\begin{tabular}{|c|c|c|c|c|c|}
\hline Lithology & GR (gAPI) & RES (ohm.m) & DEN (g/cc) & NEU (dec) & DTC (ms/ft) \\
\hline Sandstone & $68-150$ & $2.75-34.9$ & $2.01-2.18$ & $0.29-0.35$ & $108-171$ \\
\hline Conglomeratic sandstone & $78-110$ & $3.07-18.8$ & $2.04-2.20$ & $0.28-0.35$ & $140-161$ \\
\hline Siltstone & $94-132$ & $1.3-5.99$ & $2.10-2.21$ & $0.31-0.38$ & $122-155$ \\
\hline Shale & $90-124$ & $1.37-2.08$ & $2.10-2.23$ & $0.38-0.46$ & $106-162$ \\
\hline Diamictite & $129-159$ & 1 & $2.19-2.21$ & 0.45 & $138-147$ \\
\hline Marl & $51-60$ & $1.51-2.4$ & $2.09-2.32$ & $0.31-0.4$ & $92-106$ \\
\hline
\end{tabular}

Studies on the Campos Basin (Chang et al., 2006; Stevanato, 2011) describe the presence of arcosian sandstones (sandstones composed of feldspars containing potassium) from the Cenomanian/Turonian on the Namorado Field. Furthermore, according to ANP (2014), turbiditic reservoirs of the Upper Maastrichtian/Lower Oligocene of the Jubarte Field are predominantly arcosian in composition, which is in accordance with the rock descriptions of Well 4-BRSA420 and builds up to the interpretation that the sandstone lithologies presented in this work might be arcosian as well.

Thus, the interpretation of the sandstone zones in this work should be guided by the density and neutron porosity log measurements combined to the interpretation of the gamma-ray log.

In order to investigate the clay presence in the sandstones and highlight the relevance of the rock-log calibration, petrophysical studies were conducted to calculate the clay volume and the porosity of the turbiditic reservoirs. It is suggested the comparison of two scenarios, in which the clay volume is calculated by two methods: using the Larionov equation and using the density and neutron logs. In addition, the reservoirs porosities are evaluated by three methods, using the density, neutron and sonic logs. The results are shown in Figure 3 on the interval 2581/2609m.

The Larionov method to obtain the clay volume is based on the GR log and on the age of the rock evaluated, considered by Nery (2013) a realistic calculation. This equation presents two variations based on the age of the rock: younger or older than the tertiary. The age of the rock accounts for the degree of compaction, diagenesis and presence of radioactive elements. Hence, since this work studies reservoirs from the Oligocene, the Larionov equation for rocks younger than the tertiary is the most adequate for thepetrophysical analysis.

Although, considering the feldspars presence on the turbiditic reservoirs, a method that does not considers the
GR log, and consequently the potassium radioactivity, is also recommended for comparison. Thus, the neutrondensity method to calculate clay volume was used to evaluate whether the high GR measurements on the sandstones are associated with the presence of clay or not. The comparison between both methods can support this investigation.

In Figure 3, analyzing the clay volume curves obtained by the two methods described before, it is observed that the Larionov method presents low volumes of shale on the sandstones, because of the high gamma-ray measures that define the clean sand base value on the GRI (Table 1 ). The clay volume evaluation from the density and neutron method exhibits higher volumes in sandstones when compared to the Larionov method.

In addition, it can be interpreted on Figure 3 that the neutron and density porosity logs correlate more coherently with the lithological variations described on the lithology log, while the sonic porosity log shows less sensibility in measures along the formations. It is observed that the measurements of the sonic porosity (PHIS) curve are higher when compared to the PHID and NEU curves. Therefore, the porosity calculated from the sonic log estimates a more optimistic scenario for the sandstone reservoirs. The reason for the higher porosity on PHIS curve might be associated with the effect of fluid formation pressure over the pore pressure in unconsolidated rocks (Nery, 2013).

This causes the sonic measurement to calculate a higher proportion of fluid in relation to the matrix, overestimating the true formation porosity. Hence, it can be concluded in Figure 3 that the density and neutron porosities are more appropriate to analyze the total porosity in sandstone formations than the sonic porosity. Table 2 summarizes the mean petrophysical measures evaluated for the sandstones of the Carapebus Fm. on the interval from 2581 to $2609 \mathrm{~m}$. This table demonstrates the expressive increase on the clay volume evaluation in sandstones using the neutron density method, as well as the 
overestimation of the porosity on the sonic method compared to the density and neutron porosities.

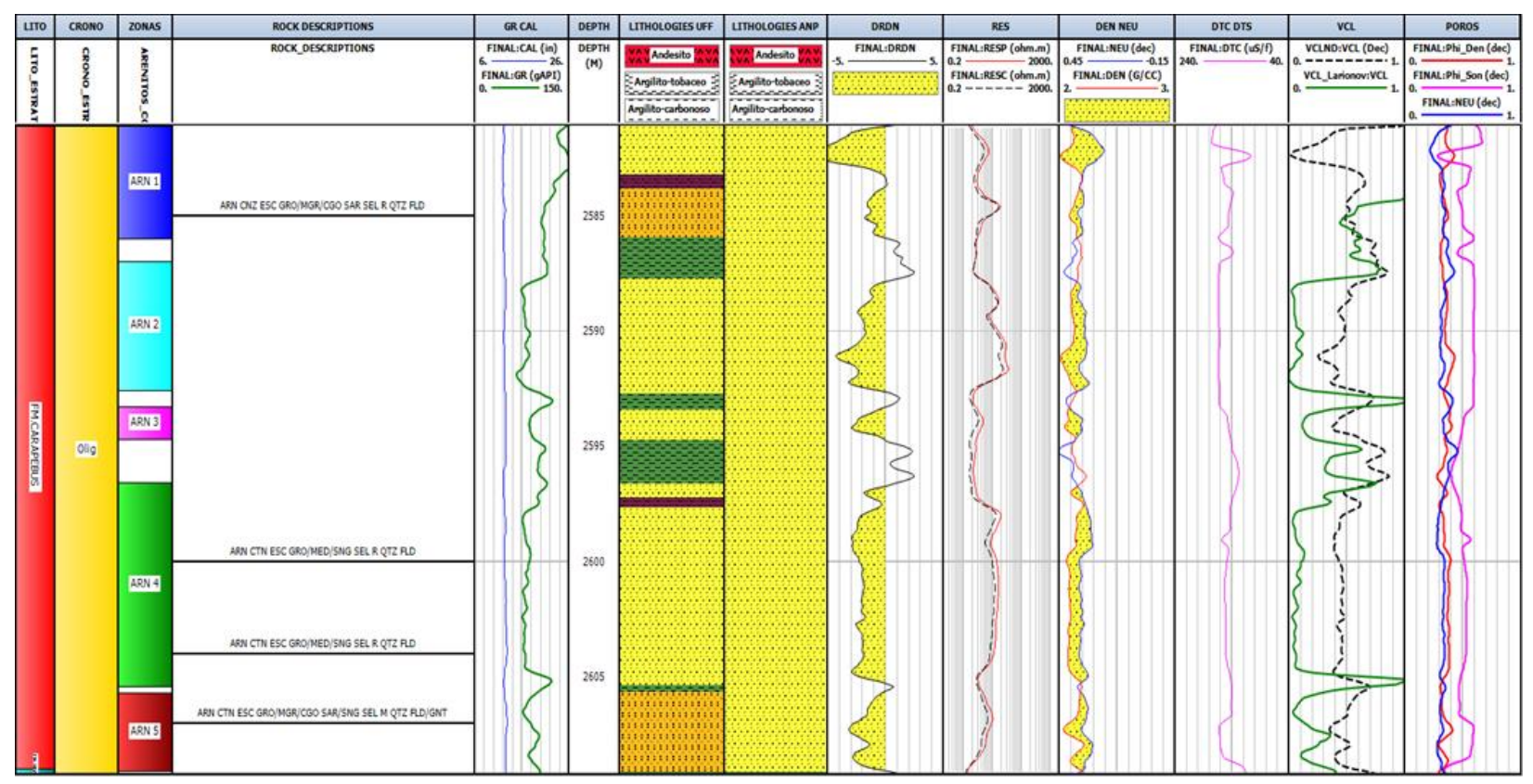

LITHOLOGY SHADING LEGEND

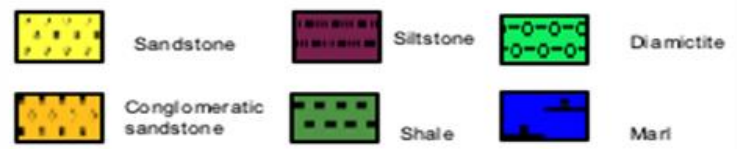

Figure 3: Logs and rock descriptions of well 4-BRSA-420, interval 2581/2609m. Track 1: lithostratigraphy; Track 2 - Chronostratigraphy; Track 3 - zones; Track 4: rock samples descriptions; track 5 - GR and CAL logs; Track 6 - depth; Track 7 - lithology log interpreted; Track 8 - lithology log provided by the Composite Log (ANP); Track 9 - DRDN log; Track 10 - RES log; Track 11 - DEN and NEU logs; Track 12 DTC log; Track 13: VCL logs; Track 14: porosity logs.

Table 2: Mean petrophysical measurements for each sandstone reservoir interpreted.

\begin{tabular}{|c|c|c|c|c|c|}
\hline Reservoirs & $\mathrm{VCL}_{\text {Larionov }}$ & $\mathrm{VCL}_{\mathrm{ND}}$ & $\mathrm{PHI}_{\mathrm{DEN}}(\mathrm{dec})$ & $\mathrm{NEU}(\mathrm{dec})$ & $\mathrm{PHI}_{\text {SON }}(\mathrm{dec})$ \\
\hline Sandstone 1 & 0.833 & 0.6903 & 0.3509 & 0.3122 & 0.4363 \\
\hline Sandstone 2 & 0.137 & 0.7199 & 0.3629 & 0.3372 & 0.593 \\
\hline Sandstone 3 & 0.1755 & 0.7401 & 0.3792 & 0.3514 & 0.4885 \\
\hline Sandstone 4 & 0.1457 & 0.7431 & 0.3603 & 0.3243 & 0.4728 \\
\hline Sandstone 5 & 0.1639 & 0.7187 & 0.3416 & 0.3088 & 0.4452 \\
\hline
\end{tabular}




\section{Conclusions}

The variety of lithologies described on Well 4-BRSA-420 with the rock descriptions contributed to a more accurate interpretation of log facies. The rock-log calibration helped to recognize and individualize the sandstone and conglomeratic sandstone lithologies, as well as the diamictites and marls that may be deposited near the Carapebus Formation. The Larionov and the neutrondensity methods to calculate the clay volume showed discrepancies on the evaluation of the sandstones. Considering the high GR vales and based on descriptions of sandstone samples, it can be interpreted that the main cause to the divergence in clay volume estimation is due to the presence of feldspar minerals in the its composition. As a consequence, the clay volume estimation using the neutron-density method might be the one that quantifies the reservoir characteristics in the most realistic result.

\section{Acknowledgments}

The authors thank Senergy for the authorization of using an academic license of the software Interactive Petrophysics (IP), and to the Agência Nacional do Petróleo, Gás Natural e Biocombustíveis (ANP) for providing data for this work.

\section{References}

AGÊNCIA NACIONAL DE PETRÓLEO, GÁS NATURAL E BIOCOMBUSTIVEIS - ANP, 2014. Jubarte.

ASQUITH, G. B., KRYGOWSKI, D., GIBSON, C. R., 2004. Basic well log analysis. Tulsa: American Association of Petroleum Geologists, 16, 244.

CHANG, H. K., MIO, E., CORRÊA, F. S., CASTRO, J. C., TINEN, J. S., ASSINE, M. L., 2006. Interpretação e Mapeamento dos Sistemas Petrolíferos da Bacia de Campos. Tomo I. São Paulo: ANP/LEBAC/UNESP.

DIAS, R. M., 2018. ESTIMATIVA DE PROPRIEDADES DE RESERVATÓRIOS E ESTUDO DE VIABILIDADE 4D NO PARQUE DAS BALEIAS - BACIA DE CAMPOS. Niterói, Graduação em Geofísica. Universidade Federal Fluminense.
GUIMARÃES, M. S. B., DENICOL, P. S., GOMES, R. M. R., 2008. Avaliação e caracterização de reservatórios laminados: comparação entre as ferramentas convencionais e 0 perfil de indução multicomponente. Revista Brasileira de Geociências, 38 (1): 188-206.

MORAES, M. A. S., BLASKOVSKI, P. R., PARAIZO, P. L. $B ., 2006$. Arquitetura de reservatórios de águas profundas. Boletim de Geociências da Petrobras, 14 (1): 7-25.

MORAIS, T A., 2017. Análise sismoestratigráfica dos complexos turbidíticos do Cretáceo Superior da Bacia de Campos. Porto Alegre, Mestrado em Geociências. Universidade Federal do Rio Grande do Sul.

MUTTI, E., NORMARK, W. R., 1991. An integrated approach to the study of turbidite systems. Seismic facies and sedimentary processes of submarine fans and turbidite systems. Springer, New York, NY, 75-106.

NERY, G. G., 2013. Perfilagem Geofísica em Poço Aberto - Fundamentos Básicos com Ênfase em Petróleo. Sociedade Brasileira de Geofísica - SBGf. Rio de Janeiro. Brasil. ISBN 978-85-88690-19-6

RIDER, M. H., 2002. The geological interpretation of well logs. Sutherland, Scotland. Second Edition, RiderFrench Consulting Ltd, p. 280.

SCHUAB, F. B., 2015. INTEGRAÇÃO DO PERFIL DE RESSONÂNCIA MAGNÉTICA NUCLEAR (RMN) COM RESULTADOS DE ENSAIOS DE LABORATÓRIO EM RESERVATÓRIOS CARBONÁTICOS. Campinas, Mestrado em Ciências e Engenharia de Petróleo. Universidade Estadual de Campinas.

SOUZA, C. O., 2014. ANÁLISE DE CORRELAÇÃO LITOLOGICA A PARTIR DE DADOS DE PERFIS DE POÇOS CONVENCIONAIS DO CAMPO DE NAMORADO USANDO SOFTWARE COMERCIAL. Niterói, Graduação em Engenharia de Petróleo. Universidade Federal Fluminense.

STEVANATO, A. C. R. S., 2011. ANÁLISE PETROFÍSICA DE RESERVATÓRIOS. Campinas, Graduação em Geologia. Universidade Estadual de Campinas. 